\title{
Yield, Quality and Nutrient Uptake of Niger (Guizotia abyssinica Cass.) as Influenced by Plant Geometry, Fertilizer Level and Cycocel
}

\author{
K. R. Sandeep and V. S. Kubsad* \\ University of Agricultural Sciences, Dharwad Karnataka 580 005, India \\ *Corresponding author
}

\begin{abstract}
A B S T R A C T
A field experiment was conducted to study the effects of varying levels of plant geometry,

Keywords

Cycocel, Fertilizer level, Niger, Oil content, Planting geometry, Protein

Article Info

Accepted:

26 August 2020

Available Online:

10 September 2020

fertilizer and cycocel on yield, quality and nutrient uptake of niger (Guizotia abyssinica Cass.) under rainfed conditions at Main Agricultural Research Station, Dharwad during Kharif 2014. The experiment was laid out in randomized completely block design (factorial concept) with 18 treatment combinations with single control and three replications. The treatment consisted of three planting geometries $(30 \times 10 \mathrm{~cm}, 45 \times 10 \mathrm{~cm}$ and $60 \times 10 \mathrm{~cm})$, three fertilizer levels $(75 \% \mathrm{RDF}, 100 \% \mathrm{RDF}$ and $125 \% \mathrm{RDF})$ and two doses of cycocel spray (500 ppm and $1000 \mathrm{ppm}$ at 30 days after sowing). The results showed that the treatment combination of planting geometry of $45 \times 10 \mathrm{~cm}$ with $125 \%$ RDF and 1000 ppm cycocel spray recorded significantly higher total dry matter production (57 $\mathrm{g}$ plant $\left.^{-1}\right)$, $\mathrm{N}$ uptake $\left(37.3 \mathrm{~kg} \mathrm{ha}^{-1}\right), \mathrm{P}$ uptake $\left(9.2 \mathrm{~kg} \mathrm{ha}^{-1}\right), \mathrm{K}$ uptake $\left(10.8 \mathrm{~kg} \mathrm{ha}^{-1}\right)$, seed yield (726 kg ha $\mathrm{kg}^{-1}$ ) and stalk yield (2606 kg ha-1) as compared to other treatment combinations. There was $20.3 \%$ increase in grain yield, $19.0 \%$ increase in stalk yield, $11.5 \%$ increase in $\mathrm{N}$ uptake, $8.0 \%$ increase in $\mathrm{P}$ uptake and $9.8 \%$ increase in $\mathrm{K}$ uptake by niger over control.
\end{abstract}

\section{Introduction}

Niger (Guuizotia abyssinica Cass.) is one of the important minor oilseed crops of India. In World, niger is grown over an area of about $1.74 \mathrm{~m}$ ha with a production and productivity of $0.58 \mathrm{~m} \mathrm{t}$ and $388 \mathrm{~kg} \mathrm{ha}^{-1}$ respectively (Anon., 2017). India is considered to be the chief niger producing country in the world grown over an area of about 3.9 lakh ha with respect to area, production and productivity of 0.99 lakh tonnes and $333 \mathrm{~kg} / \mathrm{ha}$ and it ranks first with respect to area, production and productivity. In India, it contributes to about
$2 \%$ of total edible oil production (Hansons et al., 2002). In Karnataka, niger is cultivated over an area of about 14000 ha with a production and productivity of 5000 tonnes and $357 \mathrm{~kg} / \mathrm{ha}$, respectively (Anon., 2017). Generally niger is being cultivated under rainfed situations both as sole and inter crop. Being a minor Kharif oil seed crop, it is grown under lower or poor management practices leading to lower crop productivity.

The productivity potential of any crop in general and niger in particular can be exploited by the adoption of better 
agrotechniques viz., optimum sowing time, plant geometry, fertilizers, recommended variety etc. In Northern Transition Zone of Karnataka, niger is sown during II fortnight of June at 30 x $10 \mathrm{~cm}$ planting geometry. Further, there will be more of vegetative growth compared to reproductive growth due to kharif rains which results in lower crop productivity. Thus, there is need to check its excessive vegetative growth by using a growth retardant (cycocel) to divert the photosynthates to the sink. Being highly branched with elastic growth habit of the plant, the present recommended plant geometry of $30 \times 10 \mathrm{~cm}$ appears to be less which restricts production of branched and capitula. It requires wider plant geometry which helps in better growth of plant and production of more number of branches, capitula, seeds and yield. Jadhav and Deshmukh (2008) reported the significant response of niger to higher fertilizer levels. At present the recommended dose of fertilizer to niger is 20:40:20:kg N, $\mathrm{P}_{2} \mathrm{O}_{5}, \mathrm{~K}_{2} \mathrm{O} \mathrm{ha}^{-1}$ and there is need to study its response to higher fertilizer levels to increase the yield. Since the information on the above factors is quite meagre, the present investigation was undertaken to study the response of niger to planting geometries, fertilizer levels and cycocel spray under rainfed condition.

\section{Materials and Methods}

A field experiment was conducted on medium deep black soil at Main Agricultural Research Station, University of Agricultural Sciences, Dharwad, Karnataka, during Kharif 2014. The experiment was laid out in randomized completely block design with factorial concept consists of 18 treatment combinations with single control (Recommended package of practice-RPP) and three replications. The treatment consisted three planting geometries $(30 \times 10 \mathrm{~cm}, 45 \times 10 \mathrm{~cm}$ and $60 \times 10 \mathrm{~cm})$, three fertilizer levels $(75 \% \mathrm{RDF}, 100 \% \mathrm{RDF}$ and $125 \% \mathrm{RDF}$ ) and two doses of cycocel spraying (500 ppm and $1000 \mathrm{ppm}$ at 30 days after sowing). The soil of the experiment site had $\mathrm{pH} 7.2$ with low available nitrogen (190 $\left.\mathrm{kg} \mathrm{ha}^{-1}\right)$, medium available phosphorous (31.2 $\left.\mathrm{kg} \mathrm{ha}^{-1}\right)$ and high available potassium $(370 \mathrm{~kg}$ $\mathrm{ha}^{-1}$ ). Niger cv 'DNS-4' was sown@1.5 kg ha $^{-1}$ on $13^{\text {th }}$ July 2014 at a shallow depth of 2 $\mathrm{cm}$ at different planting geometries and different fertilizers was applied as per the treatments in the form of urea, diammonium phosphate and muriate of potash at the time of sowing. The crop was raised by following the recommended package of practice. The total rainfall received during the crop period was $652 \mathrm{~mm}$ which ensured adequate stored moisture for germination, emergence, early establishment of seedlings and better crop expression. Gap filling was done at 9 days after sowing to maintain optimum plant population. Thinning was carried out at twenty days after sowing retaining one healthy seedling per hill. Cycocel @ 500 ppm and 1000 ppm at 30 DAS (Days after sowing) to each treatment except control plot. All the agronomic operations except those under study were kept uniform for all the treatments. The crop was harvested on $1^{\text {st }}$ and $2^{\text {nd }}$ of November 2014. The growth and yield observations were recorded as per the established norms. Plant samples of niger collected at harvest were used for estimation of nutrient content. The dried sample were ground and passed through 40 mesh sieve. The ground material was collected in butter paper bag and used for chemical analysis. The soil samples $(0-15 \mathrm{~cm})$ so collected were air dried, ground with the help of wooden pastle and mortar, sieved through $2 \mathrm{~mm}$ sieve and analysed for available nitrogen (Alkaline Permanganate Method, Subbiah and Asija, 1956), available phosphorus (Olsen et al., 1954) and available potassium (A.O.A.C., 1988). The protein and oil content of niger was determined by Modified Lowry's method and Soxhlet apparatus using petroleum ether 
$\left(60-80^{\circ}\right.$ C) as an extractant (A.O.A.C., 1960) respectively. The data collected on different parameters were subjected to statistical analysis as described by Gomez and Gomez (1984) for better interpretation of results.

\section{Results and Discussion}

Total dry matter production, yield and quality

The data on total dry matter production, yield, oil content and protein content of niger differed significantly due to planting geometries, fertilizer levels and cycocel (Table 1). The crop sown at $45 \times 10 \mathrm{~cm}$ planting geometry recorded significantly higher total dry matter production $(52.8 \mathrm{~g}$ plant $\left.{ }^{-1}\right)$, seed yield (531 $\left.\mathrm{kg} \mathrm{ha}^{-1}\right)$, stalk yield
(2038 kg ha ${ }^{-1}$ ), oil content (39.0\%) and protein content $(23.4 \%)$ as compared to other planting geometries. The yield increase at 45 $\mathrm{x} 10 \mathrm{~cm}$ planting geometry was $19.2,14.5$ and $20.3 \%$ higher over $60 \times 10 \mathrm{~cm}, 30 \times 10 \mathrm{~cm}$ and control (RPP) respectively. These higher values were mainly due to better resource availability and reduced interplant competition in the population. Thus resulted in better performance of individual plants as indicated by more number of branches plant ${ }^{-1}$ and yield parameters. Saren et al., (2008) observed the similar response of niger to planting geometries. The higher oil and protein content can be related to congenial micro climate as well as increase in light penetration within plant canopy which increased the assimilation rate as reported by Tenebe et al., (2008).

Table.1 Total dry matter production, yield and quality of niger as influenced by planting geometry, fertilizer level and cycocel

\begin{tabular}{|c|c|c|c|c|c|}
\hline Treatments & $\begin{array}{c}\text { Total dry matter } \\
\text { production at harvest } \\
\text { DAS }\left(\mathrm{g} \text { plant }{ }^{-1}\right)\end{array}$ & $\begin{array}{c}\text { Seed yield } \\
\left(\mathrm{kg} \mathrm{ha}^{-1}\right)\end{array}$ & $\begin{array}{c}\text { Stalk yield } \\
\left(\mathrm{kg} \mathrm{ha}^{-1}\right)\end{array}$ & $\begin{array}{c}\text { Oil } \\
\text { content } \\
(\%)\end{array}$ & $\begin{array}{c}\text { Protein } \\
\text { content }(\%)\end{array}$ \\
\hline \multicolumn{6}{|l|}{ Plant geometry } \\
\hline $30 \mathrm{~cm} \times 10 \mathrm{~cm}$ & 50.2 & 454 & 1657 & 38.5 & 22.1 \\
\hline $45 \mathrm{~cm} \times 10 \mathrm{~cm}$ & 52.8 & 531 & 2038 & 39.0 & 23.4 \\
\hline $60 \mathrm{~cm} \times 10 \mathrm{~cm}$ & 52.3 & 429 & 1590 & 38.1 & 22.8 \\
\hline S. Em. \pm & 0.28 & 3 & 14 & 0.13 & 0.2 \\
\hline CD @ 5\% & 0.79 & 9 & 40 & 0.37 & 0.6 \\
\hline \multicolumn{6}{|l|}{ Fertilizer levels } \\
\hline $75 \%$ RDF & 50.8 & 431 & 1652 & 38.2 & 22.3 \\
\hline $100 \%$ RDF & 52.1 & 475 & 1755 & 38.2 & 22.5 \\
\hline $125 \%$ RDF & 52.4 & 508 & 1879 & 39.1 & 23.5 \\
\hline S. Em. \pm & 0.28 & 3 & 14 & 0.13 & 0.2 \\
\hline CD@ $@ 5 \%$ & 0.79 & 9 & 40 & 0.37 & 0.6 \\
\hline \multicolumn{6}{|l|}{ Cycocel } \\
\hline $500 \mathrm{ppm}$ & 51.1 & 456 & 1711 & 38.5 & 22.3 \\
\hline 1000 ppm & 52.4 & 486 & 1813 & 38.6 & 22.3 \\
\hline S. Em. \pm & 0.22 & 3 & 12 & 0.10 & 0.2 \\
\hline CD@ $@$ 5\% & 0.65 & 7 & 33 & NS & NS \\
\hline
\end{tabular}


Table.2 Nutrient uptake and availability of niger as influenced by planting geometries, fertilizer levels and cycocel spray

\begin{tabular}{|c|c|c|c|c|c|c|}
\hline 9.5 & $\begin{array}{r}\text { N uptake } \\
\left(\text { kg ha }^{-1}\right)\end{array}$ & $\begin{array}{l}\text { P uptake } \\
\left(\mathrm{kg} \mathrm{ha}^{-1}\right)\end{array}$ & $\begin{array}{l}\text { K uptake } \\
\left(\text { kg ha }^{-1}\right)\end{array}$ & $\begin{array}{c}\text { Available } \\
\text { nitrogen (kg/ha) }\end{array}$ & $\begin{array}{c}\text { Available phosphorus } \\
\text { (kg/ha) }\end{array}$ & $\begin{array}{c}\text { Available } \\
\text { potassium (kg/ha) }\end{array}$ \\
\hline \multicolumn{7}{|l|}{ Plant geometry } \\
\hline $30 \mathrm{~cm} \times 10 \mathrm{~cm}$ & 31.8 & 8.3 & 9.8 & 174.4 & 37.3 & 376.1 \\
\hline $45 \mathrm{~cm} \times 10 \mathrm{~cm}$ & 33.1 & 8.7 & 10.2 & 173.9 & 36.9 & 375.9 \\
\hline $60 \mathrm{~cm} \times 10 \mathrm{~cm}$ & 27.9 & 7.6 & 9.0 & 178.6 & 37.8 & 377.1 \\
\hline S. Em. \pm & 0.3 & 0.04 & 0.05 & 0.3 & 0.2 & 0.08 \\
\hline CD@ $9 \%$ & 0.8 & 0.12 & 0.14 & 0.8 & 0.5 & 0.22 \\
\hline \multicolumn{7}{|l|}{ Fertilizer levels } \\
\hline 75\% RDF & 30.4 & 8.0 & 9.5 & 171.1 & 29.8 & 371.5 \\
\hline $100 \%$ RDF & 30.5 & 8.1 & 9.5 & 176.2 & 37.9 & 376.5 \\
\hline $125 \%$ RDF & 31.8 & 8.4 & 9.9 & 179.7 & 44.3 & 381.1 \\
\hline S. Em. \pm & 0.3 & 0.04 & 0.05 & 0.3 & 0.2 & 0.08 \\
\hline CD@ $9 \%$ & 0.8 & 0.12 & 0.14 & 0.8 & 0.5 & 0.22 \\
\hline \multicolumn{7}{|l|}{ Cycocel } \\
\hline $500 \mathrm{ppm}$ & 30.3 & 8.1 & 9.5 & 176.2 & 37.6 & 376.5 \\
\hline 1000 ppm & 31.5 & 8.3 & 9.8 & 175.1 & 37.1 & 376.3 \\
\hline S. Em. \pm & 0.2 & 0.03 & 0.04 & 0.2 & 0.2 & 0.06 \\
\hline CD@ $@$ \% & 0.6 & 0.10 & 0.11 & 0.6 & 0.4 & 0.18 \\
\hline
\end{tabular}

Table.3 Interaction effects of planting geometry, fertilizer level and cycocel

\begin{tabular}{|c|c|c|c|c|c|c|c|c|c|c|c|}
\hline $\begin{array}{c}\text { Treatment } \\
\text { combinations }\end{array}$ & $\begin{array}{c}\text { Seed } \\
\text { yield (kg } \\
\left.\text { ha }^{-1}\right)\end{array}$ & $\begin{array}{c}\text { Stalk } \\
\text { yield (kg } \\
\left.\text { ha }^{-1}\right)\end{array}$ & $\begin{array}{c}\text { Oil } \\
\text { content } \\
(\%)\end{array}$ & $\begin{array}{c}\text { Protein } \\
\text { content } \\
(\%)\end{array}$ & $\begin{array}{c}\text { Total dry } \\
\text { matter } \\
\text { produ ction } \\
\left.\text { (g plant }^{-1}\right)\end{array}$ & $\begin{array}{c}\mathbf{N} \\
\text { uptake } \\
\left(\mathrm{kg} \mathrm{ha}^{-1}\right)\end{array}$ & $\begin{array}{c}\text { P } \\
\text { uptake }_{\left(\mathrm{kg} \mathrm{ha}^{-1}\right)}\end{array}$ & $\begin{array}{l}\text { K uptake } \\
\left(\text { kg ha }^{-1}\right)\end{array}$ & $\begin{array}{c}\text { N availa } \\
\text { bility } \\
\left(\mathrm{kgha}^{-1}\right)\end{array}$ & $\begin{array}{c}\text { P availa } \\
\text { bility } \\
\left(\mathrm{kg} \mathrm{ha}^{-1}\right)\end{array}$ & $\begin{array}{c}\text { K availa } \\
\text { bility } \\
\left(\text { kgha }^{-1}\right)\end{array}$ \\
\hline $\mathbf{P}_{1} \mathbf{F}_{1} \mathbf{C}_{1}$ & 437 & 1629 & 37.6 & 21.2 & 48.8 & 30.6 & 8.0 & 9.5 & 168.8 & 31.2 & 371.0 \\
\hline $\mathbf{P}_{1} \mathbf{F}_{1} \mathbf{C}_{2}$ & 450 & 1663 & 38.5 & 22.5 & 51.0 & 31.5 & 8.1 & 9.9 & 168.8 & 35.4 & 370.8 \\
\hline $\mathbf{P}_{1} \mathbf{F}_{2} \mathbf{C}_{1}$ & 438 & 1630 & 38.5 & 22.3 & 51.0 & 32.0 & 8.0 & 9.7 & 176.0 & 38.7 & 376.8 \\
\hline $\mathbf{P}_{1} \mathbf{F}_{2} \mathbf{C}_{2}$ & 469 & 1683 & 38.3 & 21.9 & 50.3 & 32.0 & 8.3 & 9.9 & 175.0 & 36.9 & 376.2 \\
\hline $\mathbf{P}_{1} \mathbf{F}_{3} \mathbf{C}_{1}$ & 430 & 1383 & 39.0 & 22.4 & 49.1 & 32.3 & 8.3 & 9.8 & 178.9 & 43.5 & 381.4 \\
\hline $\mathbf{P}_{1} \mathbf{F}_{3} \mathbf{C}_{2}$ & 498 & 1953 & 39.3 & 22.2 & 51.2 & 32.3 & 8.5 & 9.9 & 179.3 & 43.0 & 380.7 \\
\hline $\mathbf{P}_{2} \mathbf{F}_{1} \mathbf{C}_{1}$ & 449 & 1845 & 38.9 & 22.8 & 49.4 & 31.5 & 8.5 & 10.0 & 170.6 & 33.8 & 371.3 \\
\hline $\mathbf{P}_{2} \mathbf{F}_{1} \mathbf{C}_{2}$ & 399 & 1551 & 38.1 & 23.0 & 51.1 & 32.2 & 8.6 & 10.0 & 169.7 & 35.2 & 371.3 \\
\hline $\mathbf{P}_{2} \mathbf{F}_{2} \mathbf{C}_{1}$ & 519 & 2031 & 38.8 & 22.7 & 52.2 & 31.3 & 8.3 & 10.0 & 175.3 & 37.9 & 375.9 \\
\hline $\mathbf{P}_{2} \mathbf{F}_{2} \mathbf{C}_{2}$ & 562 & 2155 & 38.4 & 23.3 & 54.2 & 32.7 & 8.6 & 10.1 & 174.3 & 37.6 & 375.9 \\
\hline $\mathbf{P}_{2} \mathbf{F}_{3} \mathbf{C}_{1}$ & 529 & 2041 & 39.6 & 23.1 & 52.9 & 33.7 & 8.8 & 10.2 & 178.6 & 41.1 & 380.6 \\
\hline $\mathbf{P}_{2} \mathbf{F}_{3} \mathbf{C}_{2}$ & 726 & 2606 & 40.1 & 25.5 & 57.0 & 37.3 & 9.2 & 10.8 & 174.8 & 40.9 & 380.3 \\
\hline $\mathbf{P}_{3} \mathbf{F}_{1} \mathbf{C}_{1}$ & 412 & 1660 & 38.2 & 22.5 & 52.2 & 27.0 & 7.2 & 8.6 & 174.7 & 35.9 & 372.4 \\
\hline $\mathbf{P}_{3} \mathbf{F}_{1} \mathbf{C}_{2}$ & 420 & 1392 & 37.4 & 22.1 & 52.2 & 27.8 & 7.4 & 9.0 & 173.9 & 37.8 & 372.2 \\
\hline $\mathbf{P}_{3} \mathbf{F}_{2} \mathbf{C}_{1}$ & 432 & 1574 & 37.7 & 20.8 & 52.4 & 27.8 & 7.4 & 8.8 & 178.5 & 37.7 & 377.2 \\
\hline $\mathbf{P}_{3} \mathbf{F}_{2} \mathbf{C}_{2}$ & 430 & 1628 & 38.5 & 24.1 & 52.7 & 28.3 & 7.8 & 8.9 & 178.1 & 38.1 & 377.2 \\
\hline $\mathbf{P}_{3} \mathbf{F}_{3} \mathbf{C}_{1}$ & 457 & 1601 & 38.4 & 22.5 & 52.1 & 26.9 & 7.8 & 9.0 & 184.4 & 41.1 & 382.0 \\
\hline $\mathbf{P}_{3} \mathbf{F}_{3} \mathbf{C}_{2}$ & 424 & 1687 & 38.6 & 24.9 & 52.4 & 29.2 & 8.0 & 9.6 & 182.0 & 41.3 & 381.7 \\
\hline Control & 423 & 1650 & 38.0 & 20.4 & 48.5 & 29.3 & 8.0 & 9.2 & 177.0 & 38.3 & 376.8 \\
\hline S. Em. \pm & 8 & 35 & 0.31 & 0.5 & 0.67 & 0.6 & 0.10 & 0.12 & 0.7 & 0.7 & 0.19 \\
\hline CD@ $@ 5 \%$ & 22 & 99 & NS & 1.5 & NS & NS & NS & NS & NS & NS & NS \\
\hline \multicolumn{12}{|c|}{ Control (RPP)vs Treatment } \\
\hline S. Em. \pm & 7 & 34 & 0.30 & 0.5 & 0.67 & 0.7 & 0.10 & 0.12 & 0.7 & 0.7 & 0.21 \\
\hline CD @ 5\% & 21 & 97 & 0.87 & 1.5 & 1.91 & 1.9 & 0.30 & 0.33 & 2.0 & 1.9 & 0.60 \\
\hline
\end{tabular}


There was linear increase both in seed and stalk yield with increase in RDF from $75 \%$ to $125 \%$. Among the fertilizer levels, application of $125 \%$ RDF recorded significantly higher total dry matter production (52.4 $\left.\mathrm{g} \mathrm{plant}^{-1}\right)$, seed yield $\left(508 \mathrm{~kg} \mathrm{ha}^{-1}\right)$, stalk yield $(1879 \mathrm{~kg}$ $\left.\mathrm{ha}^{-1}\right)$, oil content $(39.1 \%)$ and protein content $(23.5 \%)$ over $100 \%$ RDF and $75 \%$ RDF. The increase in yield with $125 \% \mathrm{RDF}$ was to the tune of $6.5,15.2$ and $16.7 \%$ higher compared to $100 \% \mathrm{RDF}, 75 \% \mathrm{RDF}$ and control (RPP) respectively. The higher yield can be related to better performance of growth and yield parameters at higher fertilizer level which was due to better availability of nutrients to the crop. This has favoured the growth and development of better root system and helped in better uptake of applied nutrients. Thus resulted in increased leaf area, dry matter production and its accumulation in reproductive parts as reported by Jadhav and Deshmukh (2008). The higher protein content at $125 \%$ RDF might be due to higher nitrogen uptake and also phosphorus which is a major constituent of fatty acids and thus resulted into higher oil content and protein content as reported by Amare et al., (2015).

Application of cycocel @ 1000 ppm at 30 DAS recorded significantly higher total dry matter production $\left(52.4 \mathrm{~g} \mathrm{plant}^{-1}\right)$, seed yield (486 $\left.\mathrm{kg} \mathrm{ha}^{-1}\right)$, stalk yield (1813 $\left.\mathrm{kg} \mathrm{ha}^{-1}\right)$, oil content $(38.6 \%)$ and protein content $(22.3 \%)$ as compared to $500 \mathrm{ppm}$ cycocel spray. The increase in seed yield was to an extent of 6.2 and $12.9 \%$ over 500 ppm and control (RPP) respectively. The higher yield at $1000 \mathrm{ppm}$ cycocel spray can be attributed to its reduced plant height which was found to be useful in increasing the efficiency of translocation of photosynthates from source to sink as observed by Vasanth Kumar (2012). Thus resulted in improvement in growth and yield parameters (Kubsad et al., 2004). There was no effect of cycocel on oil content and protein content of niger.

\section{Uptake of nutrients and their availability in soil}

The results revealed the significant effect of different treatments on nutrient uptake and their availability in soil after crop harvest (Table 2). The crop sown at $45 \times 10 \mathrm{~cm}$ planting geometry recorded significantly higher $\mathrm{N}$ uptake $\left(33.1 \mathrm{~kg} \mathrm{ha}^{-1}\right), \mathrm{P}$ uptake (8.7 $\mathrm{kg} \mathrm{ha}{ }^{-1}$ ) and $\mathrm{K}$ uptake (10.2 $\left.\mathrm{kg} \mathrm{ha}^{-1}\right)$ as compared to $30 \times 10 \mathrm{~cm}$ and $60 \times 10 \mathrm{~cm}$ planting geometries. The $\mathrm{N}$ uptake was 3.9 and $15.7 \%$ higher, $\mathrm{P}$ uptake was 4.6 and $12.6 \%$ higher, $\mathrm{K}$ uptake was 3.9 and $11.7 \%$ higher over $30 \times 10 \mathrm{~cm}$ and $60 \times 10 \mathrm{~cm}$ planting geometries respectively. The wider plant geometry of $60 \times 10 \mathrm{~cm}$ recorded the lowest nutrient uptake due to lowest seed and stalk yield. The higher nutrients uptake was mainly due to higher seed and stalk yield as reported by Dharma-Oraoan et al., (2010). The available $\mathrm{N}\left(173.9 \mathrm{~kg} \mathrm{ha}^{-1}\right), \mathrm{P}(36.9 \mathrm{~kg}$ $\mathrm{ha}^{-1}$ ) and $\mathrm{K}$ (375.9 $\left.\mathrm{kg} \mathrm{ha}^{-1}\right)$ content in soil after crop harvest at $45 \times 10 \mathrm{~cm}$ was lowest as compared to other plant geometries due to higher nutrient uptake by the crop (Table 2).

There was linear increase both in nutrients uptake and also in their availability in soil after crop harvest with increase in fertilizer doze from 75 to $125 \%$ RDF. Crop supplied with $125 \%$ RDF recorded significantly higher nutrient uptake $(31.8 \mathrm{~kg} \mathrm{~N}, 8.4 \mathrm{~kg} \mathrm{P}, 9.9 \mathrm{~kg} \mathrm{~K}$ $\mathrm{ha}^{-1}$ ) as compared to rest of the fertilizer dozes. The increased uptake was attributed to increased availability of nutrients in the soil which resulted in the higher dry matter production which lead to higher seed and stalk yield of niger. The results of the present investigation were in accordance with the findings of Patil et al., (2010).

The available nutrients content in soil was increased with increase in fertilizer levels from $75 \%$ to $125 \%$ RDF. The available nitrogen, phosphorous and potassium 
increased from 171.1 to $179.7,29.8$ to 44.3 and 371.5 to $381.1 \mathrm{~kg} \mathrm{ha}^{-1}$ respectively in the soil after crop harvest which might be due to the supply of nitrogen, phosphorous and potassium through fertilizers. The lower value of available nutrient with $100 \% \mathrm{RDF}$ and 75\% RDF at harvest might be attributed to poor utilization of available soil nutrient resources due to lower efficiency of above ground canopy/ source-sink relation by the crop. Similar results were also reported by Prasanna Kumara et al., (2014).

Uptake of nitrogen, phosphorus and potassium by niger at harvest was significantly higher with the application of cycocel @ 1000 ppm (31.5, 8.3 and 9.8 $\mathrm{kg} \mathrm{ha}^{-1}$ respectively) compared to cycocel @ $500 \mathrm{ppm}(30.3,8.1$ and $9.5 \mathrm{~kg} \mathrm{ha}$ respectively). The higher uptake of nutrients may be attributed to higher seed and stalk yield due to the better performance of the crop as reflected in higher values of yield parameters. These results were in accordance with the findings of Khashid et al., (2010).

\section{Interaction effects}

Interaction effect of planting geometries, fertilizer levels and cycocel had significant effect on seed yield, stalk yield and protein content of niger, while their effect on control treatment (RPP) was significant on all parameters (Table 3). A treatment combination of $45 \mathrm{~cm} \times 10 \mathrm{~cm}$ plant geometry with the fertilizer level of 125\% RDF and application of cycocel @1000@ppm at 30 DAS recorded significantly higher seed yield $\left(726 \mathrm{~kg} \mathrm{ha}^{-1}\right)$, stalk yield $\left(2606 \mathrm{~kg} \mathrm{ha}^{-1}\right)$ and protein content $(25.5 \%)$ over other treatment combinations. The higher seed yield and stalk yield was mainly attributed to higher uptake of nitrogen, phosphorus and potassium (37.3, 9.2 and $10.8 \mathrm{~kg} \mathrm{ha}^{-1}$ respectively) as reported by Jadhav and Deshmukh (2008). The $\mathrm{N}$ is essential for plant growth and also it is a constituent of all proteins and nucleic acids. Whereas $\mathrm{P}$ is essential for the production and transfer of energy in plants which might have resulted in the higher protein content of niger compared to other treatment combinations. Similar results were also reported by Vasanth Kumar (2012) in niger.

Based on the results obtained, it may be concluded that sowing of niger at a plant geometry of $45 \mathrm{~cm} \times 10 \mathrm{~cm}$ with a fertilizer level of $125 \%$ RDF and application of cycocel @ $1000 \mathrm{ppm}$ at 30 DAS found optimum to get maximum seed yield, stalk yield and protein content under rainfed conditions as compared to recommended package of practice.

\section{References}

Amare Aleminew, Getachew, A., Emayehu, Enyew adgo and Victor flors herrero., 2015, Response of Noung (Guizotia abyssinica Cass.) to NP fertilizers application and seeding rates on yield and yield components in Ebinat district, Amhara Region, Ethiopia. World Journal of Agricultural Science, 11 (2): 70-83.

Anonymous, 2017. Selected state/season-wise area, production and productivity of oilseeds in India. Ministry of Agriculture and Farmers' Welfare, Govt. of India, New Delhi.

AOAC, 1960. Official Methods of Analysis. 18th Ed. Association of Official Analysis Chemists, Washington DC, USA.

AOAC, 1988. Official Methods of Analysis. 21th Ed. Association of Official Analysis Chemists, Washington DC, USA.

Dharma-Oraoan, Pandey, V. K., Ranjan, R. and Singh, R. K., 2010. Effect of improved variety and plant geometry on niger under rainfed condition. Crop 
Research, 39(1/2/3):221-223.

Gomez, A. A., Gomez, K. A., 1984. Statistical Procedures for Agricultural Research. John Wiley and Sons. Ink., New York.

Hansons, B., Hans, K., Bryan, H., Burton, J., Grey, E and Steve, M., 2002, Niger, Thistle: Potential in North Dakota, Annual Report, 2002.

Jadhav, A.S. and Deshmukh, L.S. 2008, Response of niger (Guizotica abyssinica) to sowing time and fertility levels. Journal of Oilseeds Research, 25(2): 212-213.

Kashid, D. A., Doddamini, M. B., Chetti, M. B. Hiremath, S. M. and Aravindkumar, B. N., 2010. Effect of cycocel on morpho-physiological traits and yield in sunflower. Karnataka Journal of Agricultural Science, 23(2):347-349.

Kubsad, V. S., Rudranaik, V., Mallapur, C. P. and Hulihalli, U. K., 2004. Effect of cycocel on safflower growth and yield under rainfed vertisols condition. Journal of Oliseeds Research, 21(1):218-219.

Olsen, S. R., Cole, C. V., Watenable, F. S. and Dean, L. A., 1954. Estimation of available phosphorusi in soils by extraction with sodium bicorbonate, USDA Cir. 939, Washington DC, USA.

Patil, H. S., Deshmukh, M. R. and Ranganatha, A. R. G., 2010. Nutrient management in niger. JNKVV
Research Journal, 44(2):113-117.

Prasanna Kumara, B. M., Chittapur, B. M., Hiremath, S. M., Malligwad, L. H., Nadaf H. L. and Koti, R.V., 2014, Effect of fertilizer levels and planning geometry on the performance of sesame (Sesamum indicum L.) genotypes. Karnataka Journal of Agricultural Science, 27 (3): 289-292.

Saren, B. K., Mandal, and Bag, N., 2008. Effect of mulching and row plant geometry on growth, seed yield and oil yield of rainfed niger in red and lateritic acid belt of West Bengal. Indian Journal of Agricultural Sciences, 70(11):757-761.

Subbiah, B. V. and Asija, G. L., 1956. A rapid procedure for determination of available nitrogen in soils. Current Science, 25:259-260.

Tenebe, V.A. Pal, U.R., Okonkwo, C. A.C. and Auwalu, B.M., 2008, Response of rainfed sunflower (Helianthus annuus L.) to nitrogen rates and plant population in the semi-aid savanna region of Nigeria. Journal of Agronomy and Crop Science, 177 (3): 11-18.

Vasanth Kumar, 2012, Response of niger (Guizotia abyssinica Cass) to date of sowing, plant geometry and cycocel under rainfed condition, Dharwad, Karnataka (India).M.Sc. Thesis, University of Agricultural Sciences, Dharwad, India.

\section{How to cite this article:}

Sandeep, K. R. and Kubsad, V. S. 2020. Yield, Quality and Nutrient Uptake of Niger (Guizotia abyssinica Cass.) as Influenced by Plant Geometry, Fertilizer Level and Cycocel Int.J.Curr.Microbiol.App.Sci. 9(09): 3470-3476. doi: https://doi.org/10.20546/ijcmas.2020.909.431 